\title{
A Ricardian analysis of the impact of climate change on permanent crops in a Mediterranean region
}

\author{
Giuseppina Migliore*, Cinzia Zinnantı*, Emanuele Schimmenti*, \\ Valeria Borsellino*, Giorgio Schifani*, Caterina Patrizia Di Franco*, \\ Antonio Asciuto*
}

DOI: $10.30682 / \mathrm{nm} 1901 \mathrm{~d}$

Jel codes: Q51, Q54, R11

\begin{abstract}
This is the first study which explores the impact of climate change in Sicily, a small Mediterranean region of Southern Europe. According to research, Mediterranean area has shown large climate shifts in the last century and it has been identified as one of the most prominent "Hot-Spots" in future climate change projections. Since agriculture is an economic activity which strongly depends on climate setting and is particularly responsive to climate changes, it is important to understand how such changes may affect agricultural profitability in the Mediterranean region. The aim of the present study is to assess the expected impact of climate change on permanent crops cultivated in Sicilian region (Southern Italy). By using data from Farm Accountancy Data Network and Ensembles climatic projections for 2021-2050 period, we showed that the impact of climate change is prominent in this region. However, crops respond to climatic variations in a different manner, highlighting that unlike the strong reduction in profitability of grapevine and citrus tree, the predicted average Net Revenue of olive tree is almost the same as in the reference period (1961-1990).
\end{abstract}

Keywords: Farm profitability, Sicily, Ricardian model, Quantile regression, FADN.

\section{Introduction}

Climate changes are already facts affecting ecosystems, economy and human well-being. A growing number of studies indicate that the world is warming and will continue to warm as the concentration of greenhouse gases rises in the future (Seo and Mendelsohn, 2008a). Human activities, supported by economic growth, are considered one of the main determinants of climate change. In particular, the increasing population size and the increasing consumption of high fossil fuel energy, both for domestic use and for the industrial sector, as well as land use patterns, are the main factors influencing greenhouse gas emissions (Semenza et al., 2008). According to IPCC (2014), since 1950s greenhouse gas emissions due to anthropogenic activity showed the highest rates of growth in history: nowadays, $\mathrm{CO} 2$ atmospheric concen-

\footnotetext{
* Department of Agricultural, Food and Forestry Sciences, University of Palermo, Italy. Corresponding author: giuseppina.migliore@unipa.it
} 
trations and methane are the highest of the last 800,000 years. This has contributed to altering the Earth's energy balance, which is highly sensitive to such changes (Lanfranchi and Giannetto, 2018). The alteration of the earth's energetic balance is associated with the occurrence of extreme weather events, change of temperature and seasonal changes of weather (IPCC, 2014). This has important implications on the agricultural sector, indeed, the influence of changing climate conditions on agriculture is growing since the primary sector is the main user of water and land (Fezzi and Bateman, 2012; Ciscar et al., 2011). Production and quality of cultivated crops and their water use are directly influenced by local climate variables and atmospheric $\mathrm{CO} 2$ (Ciscar et al., 2011), such that, climate change has an important effect on the sustainable development of agriculture and food production.

If on the one hand agriculture is considered as a major contributor of global greenhouse gas emissions, which in turn contribute to amplify climate change effects, on the other hand, global food production is also among the sectors to be most affected by climate change (Ciscar et al., 2011). It has been argued that the problem of climate change can influence food availability: since saltwater intrusion and change in local climates may affect crop productivity; access to food: by changing the ability to produce food or by enhancing the price of agricultural commodities; and use patterns: by forcing a crop switch towards more adapted crop, for example from rice to wheat (Van Passel et al., 2017; Bozzola et al., 2017; Iglesias et al., 2012; Gupta, 2012). While in developing countries climate change has already heavily shown its effects, a common perception in Europe seems to be that climate change is something that is to be expected in the future (Potthast and Meisch, 2012). According to some studies, precipitation and the occurrence of extreme weather events will increase during the next years. The mean temperature in Europe is expected to increase by $2.1^{\circ} \mathrm{C}$ to $5.3^{\circ} \mathrm{C}$ by the end of this century. The entity and stress imposed by climate change on production in agriculture highlight the regional differences among European countries (IPCC, 2014; Bozzola et al., 2017; Donatelli et al., 2012; Iglesias et al., 2012; Ciscar et al., 2011). The average temperature in Europe has continued to increase with regionally and seasonally differences. In Northern Europe, climate change may have positive effects through increases in productivity and in the range of species grown, although there may be negative effects on the quality of surface waters for agricultural use (Bindi and Olesen, 2011). Conversely, Southern Europe could be subjected to higher yield losses ( $-25 \%$ by 2080 under a $5.4^{\circ} \mathrm{C}$, Ciscar et al., 2011), with a greater risk of damage and failure (IPCC, 2014; Ferrara et al., 2010; Bindi and Olesen, 2011; Ruiz-Ramos et al., 2011; Van Passel et al., 2017; Bozzola et al., 2017).

Studies on climatic projections in Europe for the current century showed that the Mediterranean is a potentially vulnerable region to climatic changes as induced, for example, by increasing concentrations of greenhouse gases (e.g. Lionello et al., 2006a; Ulbrich et al., 2006). Indeed, the Mediterranean region has shown large climate shifts during the last century and it has been identified as one of the most prominent "Hot-Spots" in future climate change projections (Giorgi and Lionello, 2008; Giorgi, 2006; Luterbacher et al., 2006). Since agriculture is an economic activity strongly dependent on climate setting and particularly responsive to climate changes, it is important to understand how such changes may affect agricultural profitability in the Mediterranean region.

Sicily is the largest island of Italy, located in the middle of the Mediterranean sea, in which climate is characterised by hot summers, mild winters and very changing middle seasons. Rainfall is generally scarce in late spring and summer proving to be insufficient to ensure water supply in some cities. Agriculture is one of the most valuable economic resources of Sicily thanks to the variety and quality of productions. The production of cereals, in particular wheat, is remarkable, as well as the cultivation of olive trees, citrus trees and grapevine. These crops assure higher revenues compared to cereals production, thus forecasting the impact of climate change on their profitability could provide useful indications in order to adopt measures aimed at minimizing the climate impacts, through specific adaptation strategies. 


\section{Ricardian approach used to assess the im- pact of climate change on agricultural profit- ability: a brief review of the literature}

Different approaches have been used to understand the impacts of climate change on agricultural profitability (Fezzi and Bateman, 2012; Mendelsohn e Dinar, 2009). At the beginning, there were two main approaches to assess the impact of climate change (Mendelsohn et al., 2007): one way is to run simulation models, the parameters of which have to be obtained from controlled experiments; the other way is to conduct a cross-sectional analysis observing the economic system across different locations in order to determine how the system may adapt to different climates. This model, usually referred to as a Ricardian approach and has been developed to explain the variation in the value of land per hectare across different climatic areas (Mendelsohn et al., 1994; Mendelsohn and Dinar, 1999; Mendelsohn et al., 2001; Mendelsohn and Dinar, 2003; Seo et al., 2005; Seo and Medelsohn, 2008; Bozzola et al., 2017). The Ricardian model regresses land value (or net revenue per hectare) against long term climate and other control variables. According to this model, cross-sectional observations concerning different climates reveal the climate sensitivity of farms in different geographical areas (Mendelsohn et al., 1994; Kabubo-Mariara et Karanja, 2007; Seo and Mendelsohn, 2008b; Mishra et al., 2016; Wood et al., 2015; Wang et al., 2009). More in depth, this approach takes an underlying production function and estimates impacts by varying one or a few input variables, such as temperature and precipitation (Mendelsohn et al., 1994). Van Passel and colleagues (2017) in a Ricardian analysis on European agriculture showed that the effects of the climatic variables are different across European countries, due to different average values of temperature and precipitation. This study provided indications of how changes in climate would affect European farms in the future. In particular, while an increase in temperature is beneficial for Northern European countries, it could be harmful in Southern European countries, including Italy (Bozzola et al., 2017; De Salvo et al., 2013).
Conversely, an increase in precipitations would benefit most European countries with exception of Scandinavian countries.

To the best of our knowledge, there are only two studies applying the Ricardian approach to assess the expected impact of climate change on Italian agriculture (Bozzola et al., 2017; De Salvo et al., 2013). Bozzola and colleagues' study (2017) deals with the impact of climate change on the whole Italian agriculture, while the De Salvo and colleagues' analysis focuses on the impact of climate change in an Alpine region; no knowledge currently exists for a specific Mediterranean area.

The aim of the present study is to assess the expected impact of climate change on agriculture on permanent crops cultivated in Sicily region (Southern Italy). The results of this study may contribute to the academic debate on the effect of climate change on the agricultural sector. Moreover, if there is enough climatic variation across the sample, the Ricardian cross-sectional analysis can provide a preliminary picture of regional agricultural systems vulnerability to climate change.

\section{Method and model specification}

The Ricardian model assumes that each farmer wishes to maximize income, subject to the exogenous conditions of their farm (Seo and Mendelson, 2008a). Specifically, the farmer chooses the crop and inputs for each unit of land that maximizes income, as it is expressed in Equation 1 (Mendelsohn et al., 1994):

$$
\begin{aligned}
& \operatorname{Max} \pi=\Sigma \mathrm{P}_{\mathrm{qi}} \mathrm{Q}_{\mathrm{i}}\left(\mathrm{X}_{\mathrm{i}}, \mathrm{L}_{\mathrm{i}}, \mathrm{K}_{\mathrm{i}}, \mathrm{IR}_{\mathrm{i}}, \mathrm{C}, \mathrm{W}, \mathrm{S}\right) \\
& -\Sigma \mathrm{P}_{\mathrm{x}} \mathrm{X}_{\mathrm{i}}-\Sigma \mathrm{P}_{\mathrm{L}} \mathrm{L}_{\mathrm{i}}-\Sigma \mathrm{P}_{\mathrm{K}} \mathrm{K}_{\mathrm{i}}-\Sigma \mathrm{P}_{\mathrm{IR}} \mathrm{IR}_{\mathrm{i}}
\end{aligned}
$$

where $\pi$ is net annual income, $\mathrm{P}_{\mathrm{qi}}$ is the market price of crop (or livestock) $i, Q_{i}$ is a production function for crop i, $X_{i}$ is a vector of annual inputs, such as seeds, fertilizers and pesticides for each crop $i, L_{i}$ is a vector of labor (hired and household) for each crop $i, K_{i}$ is a vector of capital, such as tractors and harvesting equipment for each crop $i, I R_{i}$ is a vector of irrigation choices for each crop i, $\mathrm{C}$ is a vector of climate variables, $\mathrm{W}$ is available water for irrigation, $\mathrm{S}$ 
is a vector of soil characteristics, $\mathrm{P}_{\mathrm{x}}$ is a vector of prices for the annual inputs, $\mathrm{P}_{\mathrm{L}}$ is a vector of prices for each type of labor, $\mathrm{P}_{\mathrm{K}}$ is the rental price of capital, and $\mathrm{P}_{\mathrm{IR}}$ is the annual cost of each type of irrigation system.

If the farmer chooses the crop or livestock that provides the highest net income and chooses each endogenous input in order to maximize net income, the resulting chosen net income will be a function of just the exogenous variables (Equation 2; Mendelsohn et al., 1994):

$$
\pi^{*}=\mathrm{f}\left(\mathrm{P}_{\mathrm{q}}, \mathrm{C}, \mathrm{W}, \mathrm{S}, \mathrm{P}_{\mathrm{x}}, \mathrm{P}_{\mathrm{L}}, \mathrm{P}_{\mathrm{K}}, \mathrm{P}_{\mathrm{IR}}\right)
$$

With perfect competition for land, free entry and exit will ensure that excess profits are driven to zero. Land rents will consequently be equal to net income per hectare (Ricardo, 1817; Mendelsohn et al., 1994). Land value will then reflect the present value of net revenue for each farm.

The Ricardian model regresses land value (or net revenue per hectare) against long term climate variables and other control variables. Then, projecting in the future the estimated relationship between economic performance and long run climate variables allows accounting for climate impact (De Salvo et al., 2013; Mendelson et al., 1994). The choice of the dependent variable between land value per hectare and net revenue (NR) per hectare largely depends on data availability, although none of the two choices is free from defects (Mendelsohn and Dinar, 2009).

\subsection{Data collection}

Our analysis is based upon structural and economic data from 130 individual farms specialized in grapevine, citrus trees and olive trees growing in Sicily region, included in the Farm Accountancy Data Network (FADN) ${ }^{1}$, which are considered representative of Sicilian farms.
In this study, annual NR per hectare is used since it is easily calculable from FADN and it produces the best goodness of fit, as it is obtained from gross revenue minus explicit costs (i.e. miscellaneous farm expenses, etc.), with the exception of implicit costs associated to the resources owned by the farmer (i.e. farm capital and household members labour).

The formulation of the Ricardian model adapted to individual farms is:

$$
y_{i}=f\left(C_{i j}, K_{i n}\right)+\varepsilon_{i}
$$

Where $y_{i}$ is equal to annual NR per hectare of farm $i, C_{i j}$ is a vector of the $j$ long term climatic variables associated to each farm, and $K_{\text {in }}$ is a vector of $n$ farm variables that could explain farm profitability (control variables); while $\varepsilon_{i}$ is the error term.

As Mendelsohn and colleagues (2007) suggested, we combined more years of data in order to reflect more than a single year effect. Therefore, we extracted from the FADN panel for Sicily the latest available data, including the year 2014 and $2015^{2}$, from which we calculated the average values for all variables utilized for the estimation.

Although most Ricardian model applications use seasonal climate variables (Van Passel et al., 2017; Mendelsohn and Dinar, 2009) since seasonal differences in temperature and precipitation have a significant impact on farmland productivity, the present study, similarly to other studies on small size areas (De Salvo et al., 2013; Fleischer et al., 2008), did not use seasonal data but average annual temperature and average monthly precipitations. Concerning the control variables, we tested the effect of several structural and strategic variables. Given the endogenous nature of irrigation, we modeled it by calculating the incidence of irrigated farmland on Utilized Agricultural Area (UAA) in order to

\footnotetext{
1 The Farm Accountancy Data Network (FADN) is a European system of sample surveys conducted every year to collect accountancy data from farms, with the aim of monitoring the income and business activities of EU agricultural holdings. Derived from national surveys, the FADN is the only source of microeconomic data based on harmonised bookkeeping principles. The methodology applied aims to provide representative data along three dimensions: region, economic size and type of farming.

2 In this study it was not possible to maximize NRs' time distance as in the previous years' data on NR of many farms were not available.
} 
Table 1 - List of variables implemented in the model.

\begin{tabular}{|l|c|c|c|c|}
\hline Variable & Mean & Std. Dev. & Min & Max \\
\hline Net revenue (€/ha) & $2,287.11$ & $5,147.57$ & 7.85 & $53,448.45$ \\
\hline Water requirements (olive tree=1; grapevine=2; citrus tree=3) & 2.18 & 0.68 & 1 & 3 \\
\hline Legal form (organized=1; individual family farm=0) & 0.14 & 0.35 & 0 & 1 \\
\hline Young entrepreneurs (yes=1; no=0) & 0.20 & 0.40 & 0 & 1 \\
\hline UAA (ha) & 30.76 & 63.08 & 1.20 & 526.87 \\
\hline Irrigated UAA (\% UAA) & 48.53 & 43.15 & 0 & 116.59 \\
\hline Total horsepower (hp/ha) & 135.20 & 186.74 & 0 & $1,400.41$ \\
\hline Organic certification (yes=1; no=0) & 0.35 & 0.48 & 0 & 1 \\
\hline Other certifications (yes=1; no=0) & 0.32 & 0.47 & 0 & 1 \\
\hline Farm land allotments (No.) & 2.52 & 1.10 & 1 & 5 \\
\hline Slope (basically flat=1; steep=0) & 0.56 & 0.50 & 0 & 1 \\
\hline Average annual temperature (1961-1990) & 17.14 & 1.36 & 13.70 & 19.00 \\
\hline Average monthly precipitations $(1961-1990)$ & 50.11 & 8.85 & 35.32 & 71.36 \\
\hline Zone [coastal=1; inland=0)] & 0.58 & 0.49 & 0.00 & 1.00 \\
\hline
\end{tabular}

Source: Our elaboration on FADN and Ensembles EU project data.

control its impacts on farm's income. Regarding the output (market price of crops) and input prices (e.g. fertilizer and pesticides) we assume firstly that in a small area such as Sicily, farmers share the same input and output prices and secondly that the effect of price is disaggregate. The UAA was considered as a proxy variable of farm physical size and was introduced in the model as a quadratic term as suggested by Mendelsohn and colleagues (2010). We could not use soil characteristics as a control variable because it was not easily available for each farm included in the sample. We introduced a new dummy variable which distinguished the sample of farms according to the zone where they are located: coastal vs. inland zones. This variable was however too strongly correlated with the temperature detected in the thermo-pluviometric stations located near the sample farms. We also considered the degree of land slope for each farm (basically flat vs. steep). Other control variables we added in the model concerned both the number of farm land allotments, which characterize the Sicilian farming system, and water requirements of crops grown on the farms; the latter categorized as olive trees $=1$, grapevine $=2$, and citrus trees $=3$, ranked on the basis of crop water requirements. Total horsepower per hectare has been considered in this study as a proxy variable of mechanization degree. Similarly to De Salvo and colleagues (2013), we introduced a dummy variable which aims to identify young entrepreneurs (according to Italian law) as a proxy variable for farmer's age. Individual family farms have been distinguished from organized farms via a dummy variable. The availability of information on quality certifications adopted by the Sicilian farms of the FADN panel allowed us to test the effects of both organic certification and other certifications (e.g. PDO and PGI) on NR per hectare by using dummy variables. Moreover, climatic projections of Ensembles EU project (2009) were used, which provide the representation of climate in a 30 -year period: 1961-1990 (the reference period) and 20212050. The final list of the variables used in the model is shown in Table 1.

A quantile regression was implemented in order to study the impact of a set of variables (climatic variables and control variables) on the outcome variable, NR per hectare. This method provides a complete picture about the relation- 
ships between the outcome of $y(\mathrm{NR} /$ hectare $)$ and the regressors $x_{i}$ (climate variables and control variables) at different points in the conditional distribution of $y$. Moreover, quantile regression permits us to study the impact of such variables on both the location and scale parameters of the model, allowing a richer understanding of the data (Cameron and Trivedi, 2005).

In our case we ran a $y_{0.50}$ regression, choosing the median as a statistical indicator of central tendency since a median regression is more robust to outliers than a mean regression. Finally, it does not need any assumption about the parametric distribution of regression errors, since median regression is a semiparametric approach.

\section{Results and Discussion}

The results obtained describe the effect of explanatory variables - climatic variables and control variables - on NR per hectare of the farms of Sicilian FADN panel (Table 2). Concerning regressors' signs and significance, the model shows that water requirements, young entrepreneur, squared UAA (UAA^2), organic certification and farmland slope are not significant. The coefficient of legal form is positive and statis- tically significant, showing that the organized form of entrepreneurship affects the annual NR per hectare.

As expected, also the incidence of irrigated UAA and total horsepower showed a significant and positive relationship with the dependent variable. Even the coefficient of farmland allotments is significant, although the sign of the coefficient shows a negative relationship with NR per hectare. This is a reasonable explanation, since the greater the number of farm land allotments, the higher production costs are likely to be. Looking at the quality strategies, having adopted a quality certification (e.g. DPO and PGI) is significant for the farms observed. Focusing on climatic variables, the results of the econometric model highlight that in the Sicilian farms the temperature has a negative relationship with the annual NR per hectare, while monthly precipitations show a positive relationship with higher NRs.

Turning now to the main aim of the present study, we evaluated the impact of predicted climate change scenario in the Mediterranean region on Sicilian farms' NR per hectare. Concerning the climatic projections for the current century, we used Ensembles EU project (2009),

Table 2 - Results of the Ricardian regression (median regression).

\begin{tabular}{|l|c|c|c|c|c|c|}
\hline Dep. Var: Net Revenue $(\boldsymbol{\epsilon} / \mathrm{ha})$ & Coef. & Std. Err. & $t$ & $P>|t|$ & {$[95 \%$ Conf. } & Interval] \\
\hline Water requirements & 341.98 & 173.49 & 1.97 & 0.117 & -1.65 & 685.61 \\
\hline Legal form & 418.47 & 302.77 & 1.38 & 0.042 & 98.21 & 738.72 \\
\hline Young entrepreneur & -26.81 & 227.60 & -0.12 & 0.906 & -477.59 & 423.98 \\
\hline UAA^2 $^{\prime}$ (Irrigated UAA (\% UAA) & 0.00 & 0.00 & -1.38 & 0.171 & -0.01 & 0.00 \\
\hline Total horsepower (hp/ha) & 7.10 & 2.57 & 2.76 & 0.007 & 2.00 & 12.20 \\
\hline Organic certification & 2.20 & 0.72 & 3.03 & 0.003 & 0.76 & 3.63 \\
\hline Other certifications & 273.97 & 207.13 & 1.32 & 0.189 & -136.29 & 684.22 \\
\hline Farm land allotments (No.) & 609.22 & 213.93 & 2.85 & 0.005 & 185.50 & 1032.95 \\
\hline Slope & -383.30 & 95.39 & -4.02 & 0.000 & -572.24 & -194.37 \\
\hline Average annual temperature (1961-1990) & -77.70 & 184.60 & -0.42 & 0.675 & -443.32 & 287.92 \\
\hline Average monthly precipitations (1961-1990) & -193.61 & 85.82 & -2.14 & 0.034 & -353.59 & -13.63 \\
\hline Constant & 4123.49 & 1.03 & -0.14 & 0.048 & -2.18 & 185.82 \\
\hline
\end{tabular}

Pseudo R2 $=0.20$.

Source: Our elaboration using STATA 11 software. 
Table 3 - Point and interval estimates of NR per hectare according to the two scenarios A1 and A2.

\begin{tabular}{|l|c|c|c|c|}
\hline & $\begin{array}{c}\text { Average annual } \\
\text { Temperature }\left({ }^{\circ} \mathrm{C}\right)\end{array}$ & $\begin{array}{c}\text { Average monthly } \\
\text { precipitation }(\mathrm{mm})\end{array}$ & $\begin{array}{c}\text { Average net } \\
\text { revenue }(\boldsymbol{\epsilon} / \mathrm{ha})\end{array}$ & $\begin{array}{c}\text { Confidence } \\
\text { interval range }\end{array}$ \\
\hline $\mathrm{A} 1: 1961-1990$ & 17.14 & 50.11 & $2,287.11$ & $(-5,421.57 ; 9,826.97)$ \\
\hline $\mathrm{A} 2: 2021-2050$ & 18.64 & 46.35 & $1,393.00$ & $(-5,946.39 ; 9,105.55)$ \\
\hline$\Delta(\mathrm{A})=(\mathrm{A} 1-\mathrm{A} 2)$ & 1.50 & 3.76 & -891.48 & $(-524.82 ; 721.42)$ \\
\hline$\Delta \%$ & 8.75 & -7.50 & -38.98 & $(-9.67 \% ; 7.34 \%)$ \\
\hline
\end{tabular}

Source: Our elaboration on FADN and Ensembles EU project data.

which provides the representation of climate in a 30-year period: 1961-1990 (the reference period) and 2021-2050. According to the EU project Ensembles, in the period 2021-2050, the average increase in temperature in the Mediterranean region is roughly estimated at $+1.5^{\circ} \mathrm{C}$, with a peak in summer. Moreover, an average decrease of about $7.5 \%$ of the total annual precipitations amount is projected. By calculating the predicted NR per hectare for each observed farm in accordance with the variation of each climate variable and considering the control variables with at least $20 \%$ of statistical significance, we evaluated the expected relationship between NR per hectare and climatic variables (temperature and precipitations). The expected impact of climate change on farms profitability is shown in Table 3. More in depth, the period 1961-1990 represents the reference scenario (A1), while the future scenario (A2) is 2021-2050.

NR per hectare is forecast for each farm separately according to the two scenarios. Following average value and $95 \%$ confidence intervals are calculated on the predicted NR per hectare. The difference between NRs calculated on the reference scenario (A1) and those ones determined on the future scenario provides point and interval estimates of climate change impact. The median regression predicts a decrease of annual NR per hectare equal to $891.48 € /$ ha for the whole sample, correspondent to a $39 \%$ loss. This result suggests that climate change is expected to reduce profitability in the Sicilian farms sample. This reduction is in line with what has been found in previous analyses on Italian regions and Africa, where an increase in temperature and a decrease in precipitation for 2021-2050 lead to a reduction in annual NR (De Salvo et al., 2013;
Kurukulasuriya and Mendelsohn, 2008). The main statistical measures for the two scenarios are reported in Table 4.

Focusing on the different NRs by crop grown in the Sicilian farms of the FADN panel, it emerges that crops respond to climatic variations in a different manner. In particular, as it is shown in Table 5, with an increase of $1.5^{\circ} \mathrm{C}$ of temperature and a decrease of precipitations of about $7.5 \%$, the predicted average NR of olive trees is almost the same, but with an increase of more than $50 \%$ in the median value of NR. The scenario A2 is completely different for grapevine and citrus trees, where the average NRs collapse by $38 \%$ and $51 \%$ respectively, while looking at the median value, losses seem to be smaller, except for citrus tree where the predicted NR median reduction is $20 \%$.

Olive tree's NR surprisingly maintains the ex-ante level, besides the median NR is far higher than the reference period. This result might be due to its lower water requirements and its resistance to critical environmental fac-

Table 4 - Statistical measures of NR per hectare for the two scenarios (values in euros).

\begin{tabular}{|l|c|l|c|}
\hline \multicolumn{2}{|c|}{$\begin{array}{c}\text { Scenario A1-NR per } \\
\text { hectare (1961-1990) }\end{array}$} & \multicolumn{2}{c|}{$\begin{array}{c}\text { Scenario A2 - NR per } \\
\text { hectare (2021-2050) }\end{array}$} \\
\hline Mean & $2,287.11$ & Mean & $1,393.00$ \\
\hline Median & $1,270.60$ & Median & $1,306.17$ \\
\hline $\begin{array}{l}\text { Standard } \\
\text { deviation }\end{array}$ & $5,147.57$ & $\begin{array}{l}\text { Standard } \\
\text { deviation }\end{array}$ & $1,166.00$ \\
\hline Min & 7.85 & Min & -988.62 \\
\hline Max & $53,448.45$ & Max & $4,980.22$ \\
\hline
\end{tabular}

Source: Our elaboration on FADN and Ensembles EU project data. 
Table 5 - Results of NR per crop grown in the Sicilian farms of the FADN panel (values in euros).

\begin{tabular}{|lr|lr|c|}
\hline & & \multicolumn{2}{|c|}{ Scenario A2 } & \multicolumn{1}{c|}{ RN\% Var. } \\
\hline olive tree & obs 21 & olive tree & obs 21 & \\
Mean & $1,710.42$ & Mean & $1,726.26$ & \multicolumn{1}{c|}{0.93} \\
Median & $1,283.05$ & Median & $1,935.22$ & 50.83 \\
\hline grapevine & obs 66 & grapevine & obs 66 & \\
Mean & $1,761.40$ & Mean & $1,091.83$ & -38.01 \\
Median & $1,017.83$ & Median & 934.02 & -8.23 \\
\hline citrus tree & obs 43 & citrus tree & obs 43 & \\
Mean & $3,375.65$ & Mean & $1,650.86$ & -51.09 \\
Median & $1,960.39$ & Median & $1,567.83$ & -20.02 \\
\hline
\end{tabular}

Source: Our elaboration on FADN and Ensembles EU project data.

tors (Simeone et al., 2013; Fernàndez and Moreno, 2000). This implies that olive tree could be fully taken into account by Sicilian farmers in their future adaptation strategies, especially as a valid alternative to crops which exhibit a higher sensitivity to climate change, as in the case of citrus tree and grapevine. According to these results, at current conditions, climate change will affect the whole Sicilian farms system by producing a predicted overall loss in NR equal to more than 234 million euros in 20212050 period. Therefore, effective adaptation strategies need to be fully taken into account by farmers to reduce climate change effects (Alrusheidat et al., 2016; Brance et al., 2015), and this could be carried out by implementing suitable EU measures which encourage farmers to adopt technological innovation, such as precision farming, allowing farmers greater precision in their daily activities but also helping improve the quality of weather forecasts, crop monitoring and predicting yields. With reference to our findings, if on one hand, similarly to De Salvo et al., (2013), the present study demonstrates that Ricardian approach may be suitable when applied to a small geographical area; on the other hand, from a statistical point of view the study presents, however, some limitations, mainly attributable to the large data variability, which in turn, may be influenced by the small size sample. This is particularly true for the sub-sample of olive tree farms that in our study is characterized by only 21 observa- tions, which makes a generalisation of results very difficult.

\section{Conclusions}

This is the first study which explores the impact of climate change on Sicily, a small Mediterranean region of Southern Europe. To understand the impact of climate change on permanent crops a Ricardian analysis was used. In particular, this approach takes an underlying production function and estimates impacts by varying one or a few input variables, such as temperature and precipitation. In order to test the relationship between the outcome variable, NR per hectare, and climatic variables, as well as control variables, a quantile regression was performed. Considering Ensembles' climate projections for 2021-2050 forecasting an increase in temperature of about $1.5^{\circ} \mathrm{C}$ and a decrease in precipitations of about $7.5 \%$, median regression predicts an average reduction in annual NR per hectare of $891.48 € /$ ha, corresponding to a $39 \%$ loss. However, it is worth noting that in our sample the cultivations respond in a different manner to projected climatic variations. In particular, citrus tree and grapevine showed strong reductions in annual $\mathrm{NR}$, equal to $51 \%$ and $38 \%$ respectively.

This implies that climate change will strongly affect the economic sustainability of Sicilian farms. Currently, the EU policy offers support to farmers who find themselves in financial difficulties. For example, in September 2017, it 
allowed 15 member states to increase advance payments to farmers affected by difficult climatic conditions. This increase was aimed at direct payments and some rural development payments for farmers, increasing the amount that could be paid from 16 October 2017 from $50 \%$ to $70 \%$ of the total amount for direct payments and from $75 \%$ to $85 \%$ for rural development payments. In the future, this could affect the financial capability of EU, therefore effective adaptation strategies need to be early taken into account by Sicilian farms.

However, further research is needed, in order to overcome some intrinsic limits characterising the farm sample, which makes the inference of the above results to the overall population of $\mathrm{Si}$ cilian farms rather complicated.

Therefore, further analyses might include the selection of a larger sample, preferably through face-to-face interviews with farmers, from where to collect and process a larger amount of control data, concerning for example, farm georeferentiation. This might allow us to obtain more precise information about soil, orography and topography characteristics of farmland, with a consequent improvement in the overall quality of sample data.

Moreover, with an enlarged sample, seasonal climate data might be implemented to measure more in depth the climate sensitivity of Sicilian agricultural sector.

\section{Acknowledgements}

The authors wish to thank Dr. Dario Macaluso from CREA Research Centre for Agricultural Policies and Bioeconomy who provided data from Sicilian farms of the FADN panel. Moreover, authors are grateful to the two anonymous Referees for their insightful and extremely helpful suggestions.

\section{References}

Alrusheidat J., Hammour A. and Aljaafreh S., 2016. Climate change adaptation and technology transfer: the path to disaster risk reduction in the arid and semi-arid zones. The case of Jordan. New Medit, 15(1): 2-6.
Bindi M. and Olesen J.E., 2011. The responses of agriculture in Europe to climate change. Regional Environmental Change, 11(Suppl. 1): 151-158. DOI 10.1007/s10113-010-0173-x.

Bozzola M., Massetti E., Mendelsohn R.O. and Capitanio F., 2017. A Ricardian analysis of the impact of climate change on Italian agriculture, Fondazione ENI Enrico Mattei, Working paper No. 23: 1-47. https://papers.ssrn.com/sol3/papers.cfm?abstract id=2983021. Accessed 30 October 2017.

Branca G., Lipper L. and Sorrentino A., 2015. Cost-effectiveness of climate-related agricultural investments in developing countries: a case study. New Medit, 14(2): 4-12.

Cameron A.C. and Trivedi P.K., 2005. Microeconometrics: Methods and Applications. New York: Cambridge University Press.

Ciscar J.C., Iglesias A., Feyen L., Szabó L., Van Regemorter D., Amelung B., Nicholls R., Watkiss P., Christensen O.B., Dankers R., Garrote L., Goodess C.M., Hunt A., Moreno A., Richards J., and Soria A., 2011. Physical and economic consequences of climate change in Europe. Proceedings of the National Academy of Sciences, 108(7): 26782683. DOI: http://www.pnas.org/cgi/doi/10.1073/ pnas. 1011612108 .

De Salvo M., Raffaelli R. and Moser R., 2013. The impact of climate change on permanent crops in an Alpine region: A Ricardian analysis. Agricultural Systems, 118: 23-32. DOI: https://doi.org/10.1016/j. agsy.2013.02.005.

Donatelli M., Srivastava A.K., Duveiller G. and Niemeyer S., 2012. Estimating impact assessment and adaptation strategies under climate change scenarios for crops at EU27 scale. Interntional Congress Environmental Modelling and Software. http://scholarsarchive.byu.edu/cgi/viewcontent. cgi?article $=2018 \&$ context $=$ iemssconference. Accessed 31 October 2017.

Fernández J.E. and Moreno F., 2000. Water use by the olive tree. Journal of crop production, 2(2): 101-162. DOI: http://dx.doi.org/10.1300/ J144v02n02 05 .

Ferrara R.M., Trevisiol P., Acutis M., Rana G., Richter G.M. and Baggaley N., 2010. Topographic impacts on wheat yields under climate change: two contrasted case studies in Europe. Theoretical and Applied Climatology, 99(1-2): 53-65. DOI 10.1007/ s00704-009-0126-9.

Fezzi C. and Bateman I., 2012. Non-linear effects and aggregation bias in Ricardian models of climate change (No. 2012-02). CSERGE working paper. Available at https://www.econstor.eu/bit- 
stream/10419/121953/1/717559130.pdf. Accessed 25 October 2017.

Fleischer A., Lichtman I. and Mendelsohn R., 2008. Climate change, irrigation, and Israeli agriculture: Will warming be harmful? Ecological economics, 65(3): 508-515. DOI: https://doi.org/10.1016/j. ecolecon.2007.07.014.

Giorgi F., 2006. Climate change hot-spots. Geophysical research letters, 33(8): 1-4. DOI: 10.1029/2006GL025734.

Giorgi F. and Lionello P., 2008. Climate change projections for the Mediterranean region. Global and planetary change, 63(2): 90-104. DOI: https://doi. org/10.1016/j.gloplacha.2007.09.005.

Gupta J., 2012. The global governance of climate change, forest, water, and food: normative challenges. In Potthast T. and Meisch S. (eds): Climate change and Sustainable development. Ethical perspectives on land use and food production. EurSAFE 2012. Wageningen Academic Publishers, Holland: 29-34. DOI: https://doi.org/10.3920/97890-8686-753-0_2.

Iglesias A., Quiroga S., Moneo M. and Garrote L., 2012. From climate change impacts to the development of adaptation strategies: challenges for agriculture in Europe. Climatic Change, 112(1): 143168. DOI: 10.1007/s10584-011-0344-x.

IPCC, 2014. Climate Change 2014: Impacts, Adaptation, and Vulnerability. Part B: Regional Aspects. Contribution of Working Group II to the Fifth Assessment Report of the Intergovernmental Panel on Climate Change [Barros V.R., Field C.B., Dokken D.J., Mastrandrea M.D., Mach K.J., Bilir T.E., Chatterjee M., Ebi K.L., Estrada Y.O., Genova R.C., Girma B., Kissel E.S., Levy A.N., MacCracken S., Mastrandrea P.R. and White L.L. (eds)]. Cambridge (UK) and New York (US): Cambridge University Press: 1267-1326. http://www.ipcc.ch/pdf/assessment-report/ar5/wg2/WGIIAR5-PartB_FINAL. pdf. Accessed 23 September 2017.

Lanfranchi M. and Giannetto C., 2018. A feasibility study for a project of alternative energy production in an agritourism business in Sicily. International Journal of Environmental Studies, 75(2): 334-342.

Lionello P., Malanotte-Rizzoli P., Boscolo R., Alpert P., Artale V., Li L., Luterbacher J., May W., Trigo R., Tsimplis M., Ulbrich U. and Xoplaki E., 2006. The Mediterranean climate: an overview of the main characteristics and issues. Developments in Earth and Environmental Sciences, 4: 1-26. DOI: 10.1016/S1571-9197(06)80003-0.

Luterbacher J., Xoplaki E., Casty C., Wanner H., Pauling A., Küttel M., Rutishauser T., Brönnimann
S., Fischer E., Fleitmann D., Gonzalez-Rouco F.J., García-Herrera R., Barriendos M., Rodrigo F., Gonzalez-Hidalgo J.C., Saz M.A., Gimeno L., Ribera P., Brunet M., Paeth H., Rimbu N., Felis T., Jacobeit J., Dünkeloh A., Zorita E., Guiot J., Türkes M., Alcoforado M.J., Trigo R., Wheeler D., Tett S., Mann M.E., Touchan R., Shindell D.T., Silenzi S., Montagna P., Camuffo D., Mariotti A., Nanni T., Brunetti M., Maugeri M., Zerefos C., DeZolt S., Lionello P., Nunes M.F., Rath V., Beltrami H., Garnier E. and Roy Ladurie E.L., 2006. Mediterranean climate variability over the last centuries: a review. Developments in Earth and environmental Sciences, 4: 27-148. DOI: https://doi.org/10.1016/S15719197(06)80004-2.

Kabubo-Mariara J. and Karanja F.K., 2007. The economic impact of climate change on Kenyan crop agriculture: A Ricardian approach. Global and planetary change, 57(3): 319-330. DOI: https://doi. org/10.1016/j.gloplacha.2007.01.002.

Kurukulasuriya P. and Mendelsohn R., 2008. A Ricardian analysis of the impact of climate change on African cropland. African Journal of Agricultural and Resource Economics, 2(1): 1-23. http://www. afjare.org/vol-2-no-1.php. Accessed 26 September 2017.

Mendelsohn R., Arellano-Gonzalez J. and Christensen P., 2010. A Ricardian analysis of Mexican farms. Environment and Development Economics, 15(2): 153-171. DOI: https://doi.org/10.1017/ S1355770X09990143.

Mendelsohn R., Basist A., Dinar A., Kurukulasuriya P. and Williams C., 2007. What explains agricultural performance: climate normals or climate variance? Climatic Change, 81(1): 85-99. DOI: https:// doi.org/10.1596/1813-9450-3350.

Mendelsohn R. and Dinar A., 1999. Climate change, agriculture, and developing countries: does adaptation matter? The World Bank Research Observer, 14(2): 277-293. DOI: https://doi.org/10.1093/ wbro/14.2.277.

Mendelsohn R., Dinar A., 2003. Climate, water, and agriculture. Land Economics, 79: 328-341. DOI: 10.3368/le.79.3.328.

Mendelsohn R., Dinar A., 2009. Land use and climate change interactions. Annu. Rev. Resour. Econ., 1(1): 309-332. DOI: https://doi.org/10.1146/annurev.resource.050708.144246.

Mendelsohn R., Dinar A. and Sanghi A., 2001. The effect of development on the climate sensitivity of agriculture. Environment and Development Economics, 6(1): 85-101. https://www.cambridge.org/core/ journals/environment-and-development-economics/ 
article/effect-of-development-on-the-climate-sensitivity-of-agriculture/8815BD45D54724935C1A9F05A932784C. Accessed 15 September 2017.

Mendelsohn R., Nordhaus W.D. and Shaw D., 1994. The impact of global warming on agriculture: a Ricardian analysis. American Economic Review, 84(4): 753-771. http://www.jstor.org/stable/ pdf/2118029.pdf. Accessed 15 September 2017.

Mishra D., Sahu N.C. and Sahoo D., 2016. Impact of climate change on agricultural production of Odisha (India): a Ricardian analysis. Regional Environmental Change, 16(2): 575-584. DOI:10.1007/ s10113-015-0774-5.

Potthast T. and Meisch S. (eds), 2012. Climate Change and Sustainable Development: Ethical Perspectives on Land Use and Food Production: EurSAFE 2012, Tübingen, Germany, 30 May-2 June 2012. Springer Science \& Business Media.

Ricardo D., 1817. On the principles of political economy and taxation. London: John Murray.

Ruiz-Ramos D.V., Hernandez-Delgado E.A. and Schizas N.V., 2011. Population status of the longspined urchin Diadema antillarum in Puerto Rico 20 years after a mass mortality event. Bulletin of Marine Science, 87(1): 113-127. DOI: https://doi. org/10.5343/bms.2010.1038.

Semenza J.C., Hall D.E., Wilson D.J., Bontempo B.D., Sailor D.J. and George L.A., 2008. Public perception of climate change: Voluntary mitigation and barriers to behavior change. American journal of preventive medicine, 35(5): 479-487.

Seo S.N. and Mendelsohn R., 2008a. A Ricardian analysis of the impact of climate change on South American farms. Chilean journal of agricultural research, 68(1): 69-79. https://www.researchgate.net/profile/ Robert_Mendelsohn/publication/262759052 Analisis_Ricardiano_del_Impacto_del_Cambio_ Climatico_en_Predios_Agricolas_en_Sudamerica/ links/53da5fde0cf2e38c633687ff.pdf. Accessed 16 September 2017.

Seo S.N. and Mendelsohn R., 2008b. Measuring impacts and adaptations to climate change: A structural Ricardian model of livestock management in Africa. Agricultural Economics, 38: 1-15. DOI: 10.1111/j.1574-0862.2008.00289.x.

Seo S.N., Mendelsohn R.O. and Munasinghe M., 2005. Climate change and agriculture in Sri Lanka: a Ricardian valuation. Environment and Development Economics, 10(5): 581-596. DOI: https://doi. org/10.1017/S1355770X05002044.

Simeone V., Tucci M., Viti R., Calabrese J. and Perri E., 2013. Linee guida per la gestione degli oliveti secolari. Journal of Food Science and Nutrition, 42: 127-163. http://www.fosan.it/system/files/ Anno 42 1 14.pdf. Accessed 9 October 2017.

Ulbrich U., May W., Li L., Lionello P., Pinto J.G. and Somot S., 2006. The Mediterranean climate change under global warming. Developments in Earth and Environmental Sciences, 4: 399-415. DOI: https:// doi.org/10.1016/S1571-9197(06)80011-X.

Van Passel S., Massetti E. and Mendelsohn R., 2017. A Ricardian Analysis of the Impact of Climate Change on European Agriculture. Environmental \& Resource Economics, 67(4): 725-760. DOI: 10.1007/s10640-016-0001-y.

Wang J., Mendelsohn R., Dinar A., Huang J., Rozelle S. and Zhang L., 2009. The impact of climate change on China's agriculture. Agricultural Economics, 40(3): 323-337. DOI: 10.1111/j.15740862.2009.00379.x.

Wood S.A. and Mendelsohn R.O., 2015. The impact of climate change on agricultural net revenue: a case study in the Fouta Djallon, West Africa. Environment and Development Economics, 20(1): 20-36. DOI: https://doi.org/10.1017/ S1355770X14000084. 